\title{
Quality of Banana Influenced By Different Varieties and Planting Materials
}

\author{
H. C. Parmar* and Vinod B. Mor \\ Agricultural Research Station, Anand Agricultural University, Jabugam-391 155, Ta. Bodeli, \\ Dist. Chhotaudepur, Gujarat, India \\ *Corresponding author
}

\begin{abstract}
A B S T R A C T
An experiment was conducted at the Agricultural Research Station, AAU, Jabugam during seasons of the year 2015-16. The experiment consisted of eight treatment combinations

\begin{tabular}{|c|}
\hline Keywords \\
\hline $\begin{array}{l}\text { Banana, Varieties, } \\
\text { Planting materials } \\
\text { Quality }\end{array}$ \\
\hline Article Info \\
\hline $\begin{array}{l}\text { Accepted: } \\
\text { 20 May } 2018 \\
\text { Available Online: } \\
\text { 10 June } 2018\end{array}$ \\
\hline
\end{tabular}
comprised of four varieties (viz. $\mathrm{V}_{1}$. Grand Naine, $\mathrm{V}_{2}$.Robusta, $\mathrm{V}_{3}$.Mahalaxmi and $\mathrm{V}_{4}$. William) and two planting materials (viz. $\mathrm{P}_{1}$. Tissue culture plants and $\mathrm{P}_{2}$. Suckers), and conducted in RBD with factorial concept with four replications. The soil of the experimental field was sandy loam in texture. All the plants were planted at $1.80 \mathrm{~m}$ spacing with one plant per hole. With regard to the quality parameters, the significantly higher value of TSS $\left(22.03^{\circ} \mathrm{B}\right)$ was observed in Grand Naine variety followed by William variety $\left(21.04{ }^{\circ} \mathrm{B}\right)$. In case of carbohydrates $(23.45 \%)$ and reducing $(13.25 \%)$ were found significantly the highest under variety Grand Naine, where non reducing sugar $(10.19 \%)$ was found not significant due to different varieties of banana. Significantly lower TSS, Carbohydrates, Reducing and non-reducing sugars were observed in variety Mahalaxmi. Planting of banana through tissue culture plants significantly increased carbohydrates (22.79) and non-reducing sugar $(10.20 \%)$ than planting through suckers, but in case of TSS and Reducing sugar were significantly found unchanged due to different planting materials.
\end{abstract}

\section{Introduction}

Banana is a globally major important and economical fruit crop which is said to be a "Common Man's Fruit" as the prices are within the rich of common man. Bananas are grown in more than 150 countries, producing 105 million tonnes of fruit per year.

During the year of 2012-13 the global area of banana cultivation is 5.0 million ha and production of 103.63 Million Metric tonnes with productivity of 20.7 tonnes. In India banana cultivated around the area of 7.76 lakh ha (15.5\% of world) and total production 26.5 million metric tonnes $(25.58 \%$ of the world) with the productivity of 34.2 tonnes/ha during the year of 2012-13. Main banana growing states are Tamil Nadu, Maharashtra, Gujarat, Andhra Pradesh, Karnataka, Madhya Pradesh, Assam and West Bengal. Tamil Nadu stands first in the area and production of banana, while Gujarat second in production. During the year of 2012-13 in Gujarat total area under banana cultivation is about 71 thousand hectare and total production is 4.52 million metric tonnes. The Gujarat state productivity of Banana is 64.1 t/ha (DAC, 2015). 
In middle Gujarat, the banana cultivation is mainly concentrated in Kheda, Anand, Vadodara and Chhota Udepur districts. In Chhota Udepur district banana is mainly grown in Bodeli, Sankheda and some parts of Pavi-Jetpur talukas. This crop has great export potentiality particularly in Gulf districts (DAC, 2015).

Commercially, bananas are classified as dessert types and culinary types. The culinary types have starchy fruits and are used in the mature unripe form as vegetables. Important cultivars include Dwarf Cavendish, Robusta, Maha laxmi, William, Monthan, Poovan, Nendran, Red banana, Nyali, Safed Velchi, Basrai, Ardhapuri, Rasthali, Karpurvalli, Karthali and Grand Naine etc. (Gogoi et al., 2015). Bananas are extremely popular due to their sensorial and nutritional characteristics. They are rich in carbohydrates (20.3-29.3 g $100 \mathrm{~g}-1)$ and mineral salts such as calcium (0.6-0.8 mg $100 \mathrm{~g}-1)$, magnesium (24-30 mg $100 \mathrm{~g}-1)$, phosphorus (16-29 mg $100 \mathrm{~g}-1)$ and potassium (264-387 mg $100 \mathrm{~g}-1)$. Together with rice, wheat and corn, banana is considered one of the most important global foods (Perrier, 2011).

Despite the wide range of varieties existing in India, only a few cultivars have agronomic traits and fruit quality considered suitable for commercial exploitation (Roque, 2014). In the interest of the health conscious consumerism a systematic and comprehensive study into the quality analysis of banana, as it was lacking in this part of the country. This study was carried out to get an overall scientific comparison of the common man's fruit-the banana.

\section{Materials and Methods}

An experiment was conducted at the Agricultural Research Station, Anand Agricultural University, Jabugam which comes under Middle Gujarat Agro-Climate
Zone-III during seasons of the year 201516.The experiment consisted of eight treatment combinations comprised of four varieties (viz. $\mathrm{V}_{1}$.Grand Naine, $\mathrm{V}_{2}$.Robusta, $\mathrm{V}_{3}$.Mahalaxmi and $\mathrm{V}_{4}$. William) and two planting materials (viz. $\mathrm{P}_{1}$.Tissue culture plants and $\mathrm{P}_{2}$. Suckers), and conducted in RBD with factorial concept with four replications. The soil of the experimental field was sandy loam in texture, low in $\mathrm{OC} \%$ and available $\mathrm{N}$, medium in available $\mathrm{P}_{2} \mathrm{O}_{5}$ and $\mathrm{K}_{2} \mathrm{O}$. All the plants were planted at $1.80 \mathrm{~m}$ spacing with one plant per hole. Total soluble solid of the pulp was recorded by the using hand refractometer (Digital Hand-held "Pocket" Refractometer PAL, ATAGO). The result were presented ${ }^{\circ}$ Brix of TSS. Reducing sugar and non-reducing sugar are estimated by titrimatic method of Lane and Eynon described by Rangana (1979). Carbohydrates also estimated by method described in Manual of analysis of fruit and vegetable products by Rangana (1979).

\section{Results and Discussion}

The significantly higher value of TSS (22.03 ${ }^{\circ}$ B) was observed in Grand Naine variety followed by William variety $\left(21.04{ }^{\circ} \mathrm{B}\right)$ in mean value of planting materials. Variety Mahalaxmi recorded minimum value for TSS $\left(20.65^{\circ} \mathrm{B}\right)$ followed by Robusta $\left(20.76^{\circ} \mathrm{B}\right)$. For agro-businesses, high levels of TSS are desirable because less fruit is needed for the product concentration (Nascimento et al., 2003, Jyothi et al., 2016, Vagadiya et al., 2016). In case of carbohydrates was observed significantly the highest in variety Grand Naine $(23.45 \%)$, where significantly the lowest value for carbohydrates was noticed in variety Mahalaxmi (21.86 \%). Variety Grand Naine was found superior in case of reducing sugar $(13.25 \%)$ which was significantly the highest and significantly the lowest reducing sugar was recorded in variety Mahalaxmi $(11.99 \%)$. 
Table.1 Quality parameters of banana variety influenced by planting materials

\begin{tabular}{|c|c|c|c|c|c|c|c|c|c|c|c|c|}
\hline & \multicolumn{3}{|c|}{ TSS $\left({ }^{\circ} \mathbf{B}\right)$} & \multicolumn{3}{|c|}{ Carbohydrates \% } & \multicolumn{3}{|c|}{ Reducing sugar \% } & \multicolumn{3}{|c|}{ Non reducing sugar \% } \\
\hline VS & $\mathrm{S}_{1}$ & $\mathrm{~S}_{2}$ & Mean & $\mathrm{S}_{1}$ & $\mathrm{~S}_{2}$ & Mean & $\mathrm{S}_{1}$ & $\mathrm{~S}_{2}$ & Mean & $\mathrm{S}_{1}$ & $\mathrm{~S}_{2}$ & Mean \\
\hline$\overline{V_{1}}$ & 22.08 & 21.98 & 22.03 & 23.62 & 23.28 & 23.45 & 13.02 & 13.48 & 13.25 & 10.60 & 9.79 & 10.19 \\
\hline $\mathbf{V}_{2}$ & 21.38 & 20.14 & 20.76 & 23.41 & 21.49 & 22.45 & 11.93 & 13.24 & 12.58 & 11.47 & 8.25 & 9.86 \\
\hline $\mathbf{V}_{3}$ & 20.00 & 21.30 & 20.65 & 21.71 & 22.01 & 21.86 & 12.52 & 11.46 & 11.99 & 9.18 & 10.55 & 9.87 \\
\hline $\mathbf{V}_{4}$ & 21.25 & 20.83 & 21.04 & 22.42 & 22.44 & 22.43 & 12.87 & 12.36 & 12.62 & 9.55 & 10.08 & 9.81 \\
\hline Mean & 21.18 & 21.06 & & 22.79 & 22.30 & & 12.59 & 12.64 & & 10.2 & 9.67 & \\
\hline & S.Em \pm & CD 0.05 & $\mathrm{CV} \%$ & S.Em \pm & CD 0.05 & $\mathrm{CV} \%$ & S.Em \pm & CD 0.05 & $\mathrm{CV} \%$ & S.Em \pm & CD 0.05 & $\mathrm{CV} \%$ \\
\hline $\mathbf{V}$ & 0.35 & 1.02 & 4.67 & 0.17 & 0.51 & 2.18 & 0.08 & 0.22 & 1.69 & 0.15 & NS & 4.36 \\
\hline $\mathbf{S}$ & 0.25 & NS & & 0.12 & 0.36 & & 0.05 & NS & & 0.11 & 0.32 & \\
\hline VS & 0.49 & NS & & 0.25 & 0.72 & & 0.11 & 0.31 & & 0.22 & 0.64 & \\
\hline
\end{tabular}


We looking towards non reducing sugar, it was found not significant due to different varieties of banana, but variety Grand Naine found maximum. The differences in reducing sugars and non-reducing sugar content of different banana varieties are due to varietal differences Venkata Subbaiah K. et al., (2013). Another reason might be due the fruit quality also depends on translocation of photosynthates from photosynthetic apparatus to the fruits and finally their metabolism inside the fruit. The increase in reducing sugar may be attributed to enzymatic conversion of starch to reducing sugar (Islam, 1998). Rapidly increased non-reducing sugar was probably due to breakdown of starch into non-reducing sugar and then that nonreducing sugar was converted into reducing sugar resulting slowly increase in nonreducing sugar. The increase in sugar content was also due to the degradation of polysaccharides into monosaccharides. The present findings was in agreement with the findings of Natesh et al., (1993) in banana. Variety Mahalaxmi observed significantly lower value for all studied quality parameters.

Planting of banana through tissue culture plants significantly increased carbohydrates $(22.79 \%)$ and non-reducing sugar $(10.20 \%)$ than planting through suckers. In case of TSS and Reducing sugar were significantly found unchanged due to different planting materials. Development of tissue culture technology has been the foundation of high quality, disease free planting material production at a mass scale, particularly in tissue culture propagated crops, Singh, H. P et al., (2011). Overall better quality of fruits was produced by these mother plants.

Interaction effect was found between different varieties and planting materials. Variety Grand Naine planting through tissue culture was recorded significantly higher carbohydrates $(23.62 \%)$ followed by Robusta planting through tissue culture $(23.41 \%)$ and Grand Naine planting through suckers (23.28 $\%)$. In case of reducing sugar, significantly higher value was observed in variety Grand Naine planting by suckers $(13.48 \%)$ being at par with Robusta planting through suckers. Non reducing sugar was noticed significantly the highest $(11.47 \%)$ when variety Robusta planting by tissue culture.

From the results, it was concluded that variety Grand naine planted through tissue culture plant was found superior in case of quality parameters viz. TSS, carbohydrates and reducing sugars.

\section{References}

Anonymous 2015, Post-harvest profile of banana, Department of Agriculture and Co-operation, Ministry of Agriculture, Govt. of India, pp 4-12 (2015).

Gogoi, Sibani, Khangia, Bipin and Baruah, Karthik 2015. Evaluation on quality parameters and economic feasibility of different banana Musa spp cultivars under Assamese Conditions. Biosci. Biotech. Res. Comm. 8(2): 193-196.

http://r0.unctad.org/infocomm/anglais/banana /market.htm

Islam, M. S. 1998. Storage life and quality of banana as affected by packaging and coating materials. M.S. thesis, Institute of Postgraduate Studies in Agriculture, Salna, Gazipur, Bangladesh.

Jyothi, J., Sudha Vani, V., Uma Jyothi, K. and Subbaramamma P. 2016. Influence of 1-methyl cyclopropene (1-mcp) on the shelf life and quality of banana cv. Grand Naine under ambient conditions. The Ecoscan, Special issue, Vol. IX: 161-16.

Nascimento, W.M.O. 2003. Selection of progenies of yellow passion fruit (Passiflora edulis f. flavicarpa) to fruit 
quality. Brazilian Journal of Tropical Fruits, 25:186-188.

Natesh B.B., Aravindakshan M. and Valsalakumari P.K. 1993. Effect of split application of fertilizers in banana Musa ABB 'Nendran'. South Indian Hort. 41: 67-73.

Patil K B and Rawale K P 2009. Pre and postharvest management of banana for domestic and export market, in the Proceedings of Second National Conference on Production of Healthy Planting Material in Banana, held during October 3 - 6, 2009 at Jalgaon MS.

Perrier, X. 2011. Multidisciplinary perspectives on banana (Musa spp.) domestication. Proceedings of the National Academy of Sciences of the USA, Washington, DC, v. 108 (28), p. 1311-1318.

Rangana, S. 1979. Manual of analysis of fruit and vegetable products. Tata McGraw Hill Publishing Company Limited, New Delhi, India.
Roque, R. L. 2014. Desempenho agronômico de genótipos de bananeira no Recôncavo da Bahia. Revista Brasileira de Fruticultura, Jaboticabal, 36 (3), p. 598- 609.

Singh, H. P., Uma, S., Selvarajan, R. and Karihaloo, J. L. 2011. Micropropagation for production of quality banana planting material in asia-pacific. AsiaPacific Consortium on Agricultural Biotechnology (APCoAB), New Delhi, India. P. 3.

Vagadia, P. S., Senapati, A. K., Tank, R. V., Mayani, J. M. and Kachhadia, P. A., 2016. Quality evaluation and storage study of papaya cv. Taiwan and banana cv. Grand Naine based mixed fruit bar. The Bioscan, 11(3): 1707-170.

Venkata Subbaiah, K., Jagadeesh, S. L., Reddy, Sathyanarayana and Kanamadi, V. C. 2013. Effect of varieties and pretreatments on physico-chemical and sensory quality of banana. Karnataka J. Agric. Sci., 26 (1): (115-118).

www.atago.net

\section{How to cite this article:}

Parmar H. C. and Vinod B. Mor. 2018. Quality of Banana Influenced By Different Varieties and Planting Materials. Int.J.Curr.Microbiol.App.Sci. 7(06): 2227-2231.

doi: https://doi.org/10.20546/ijcmas.2018.706.264 